\title{
DC Motor Speed Regulation Using Speech Recognition
}

\section{Pengaturan Kecepatan Motor DC Menggunakan Speech Recognition}

\author{
Firda Andriyan ${ }^{1}$, Wahyu Sapto Aji ${ }^{1,2}$ \\ ${ }^{1}$ Program Studi Teknik Elektro, Universitas Ahmad Dahlan, Indonesia \\ ${ }^{2}$ Universiti Malaysia Pahang, Malaysia
}

\section{INFORMASI ARTIKEL}

\section{Riwayat Artikel:}

Dikirimkan 13 Februari 2020,

Direvisi 23 April 2020,

Diterima 03 Januari 2021.

\section{Kata Kunci: \\ Pengaturan kecepatan, \\ Arduino Uno, \\ Motor DC, \\ Speech Recognition.}

\section{Penulis Korespondensi:}

Firda Andriyan, Wahyu Sapto Aji

Universitas Ahmad Dahlan, Kampus 4 UAD, Jln. Ring

Road Selatan, Tamanan, Banguntapan, D. I. Yogyakarta, Indonesia.

Surel/Email:

firda1500022001@webmail.ua d.ac.id,wahyusaji@gmail.com

\begin{abstract}
ABSTRAK
One of the uses of this sound technology is controlling the speed of a DC motor. Sound in the form of a spectrum signal can be converted to digital. Digital signals can be used as microcontoler input to adjust the speed of a DC motor using the PWM (pulse width modulation) method. The design of the tool uses the V3 voice recognition module to convert the voice into digital. Microcontroller as a voice data processor by changing the input voltage to a DC motor. Voice command to set DC motor speed. Based on the results of tests carried out in good environmental conditions, $90 \%$ of voice commands can be recognized. Meanwhile, in bad environmental conditions by 50\%. Manual measurement is done by entering the input voltage from 1 volt to 10 volts. The results of the comparison show that the speed is almost the same, namely 2727 rpm for manual calculation and $2915 \mathrm{rpm}$ for the whole tool. This difference occurs because the test when manually inputting the tension is not very accurate. It can be concluded that the tool is working properly and as desired. If the environmental conditions are bad only $50 \%$ can be recognized from 30 voice commands, then there is a difference in voice intonation during the training process.
\end{abstract}

Salah satu dari pemanfaatan teknologi suara ini adalah pengendalian kecepatan motor DC. Suara berupa sinyal spektrum dapat diubah menjadi digital. Sinyal digital dapat dijadikan masukan mikrokontoler untuk mengatur kecepatan motor DC menggunakan metode PWM (pulse width modulation). Perancangan alat menggunakan module voice recognition V3 untuk mengubah suara menjadi digital. Mikrokontroler sebagai pengolah data suara dengan mengubah tegangan masukan ke motor DC. Perintah suara untuk mengatur kecepatan motor DC. Berdasarkan hasil pengujian yang dilakukan dalam kondisi lingkungan yang baik sebesar $90 \%$ perintah suara yang dapat dikenali. Sedangkan dalam kondisi lingkungan yang buruk sebesar 50\%. Pengukuran manual dilakukan dengan memasukan tegangan masukan dari 1 volt sampai 10 volt. Hasil dari perbandingan menunjukkan kecepatan yang hampir sama yaitu $2727 \mathrm{rpm}$ perhitungan manual dan $2915 \mathrm{rpm}$ secara keseluruhan alat. Selisih perbedaan terjadi karena pengujian ketika memasukan tegangan secara manual tidaklah begitu akurat. Dapat disimpulkan bahwa alat bekerja dengan baik dan sesuai yang diinginkan. Jika kondisi lingkungan yang buruk hanya $50 \%$ yang dapat dikenali dari 30 perintah suara, maka ada perbedaan intonasi suara saat proses pelatihan.

This work is licensed under a Creative Commons Attribution-Share Alike 4.0

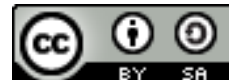

\section{Sitasi Dokumen ini:}

F. Andriyan and W. S. Aji, "DC Motor Speed Regulation Using Speech Recognition," Buletin Ilmiah Sarjana Teknik Elektro, vol. 3, no. 1, pp. 41-49, 2021. DOI: 10.12928/biste.v3i1.1751 


\section{PENDAHULUAN}

Perkembangan teknologi pada masa ke masa semakin maju, ditambah dengan adanya persaingan bebas dalam segala aspek penelitian. Penggunaan teknologi merupakan alternatif yang tidak dapat dielakkan lagi untuk memperoleh sistem kerja yang praktis, efektif, dan efisien sehingga memperoleh hasil dengan tingkat keakuratan yang tinggi. Teknologi pengenalan suara atau voice recognition adalah suatu terobosan tekonologi yang diharapkan dapat memberi kemudahan bagi penggunanya [1].

Salah satu alasan utama dari teknologi perintah suara adalah pengoperasiannya yang mudah dan tidak banyak membutuhkan tenaga. Sehingga pengoperasian sistemnya banyak diminati [2]. Perintah suara dapat dijadikan suatu pengendalian peralatan dalam rumah tangga bahkan didunia industri. Baik speech atau voice recognition dapat dilihat sebagai suatu proses di mana mesin atau program menerima dan menafsirkan dikte serta memahami dan menjalankan perintah yang diucapkan [3]. Tetapi terdapat perbedaan antara voice recognition dengan speech recognition, salah satunya teknologi voice recognition dapat mengerti kata-kata seperti yang diartikulasikan sehingga memenuhi unsur biometrik. Salah satunya adalah smart home sebagai pengendalian peralatan elektronik. Sedangkan dalam dunia industri sebagian besar dengan pengendalian motor DC sebagai penggeraknya [4].

Penerapan teknologi pengenalan suara dapat menggunakan modul voice recognition V3 sebagai pengolah suara. Suara yang berupa sinyal analog akan diubah menjadi sinyal digital oleh IC ADC pada modul voice recognition V3. Modul voice recognition V3 mampu mengidentifikasi perintah suara dari user [5]. Pada umumnya di bidang industri maupun peralatan rumah tangga menggunakan motor DC. Sehingga perkembangan teknologi elektronik semakin kedepan di buat sesederhana mungkin dengan memiliki kemampuan komputasi, kecepatan, dan dapat diandalkan [6].

Motor DC adalah jenis motor listrik yang bekerja dari sumber tegangan DC. Arah putaran motor DC ditentukan oleh arus maju atau arus berbalik dan juga tegangan positif serta tegangan negatif pada motor DC. Pengendalian kecepatan motor DC (direct current) dapat menggunakan metode PWM (pulse width modulation). Mikrokontroler dapat dijadikan kombinasi untuk membangkitkan PWM, ada 8 (delapan) tingkatan kecepatan yang bisa diatur dengan masing-masing mewakili nilai duty cycle [7] [8]. Sebagai solusi pemanfaatan PWM pada mikrokontroler dengan chip Atmega328P digunakan mengatur pulsa tegangan dan merubah PWM menjadi tegangan. Sedangkan penggunaan motor driver supaya tegangan masukan pada motor DC dapat berubah sehingga kecepatan bisa diatur. Selain sebagai pengatur kecepatan, pengedalian kecepatan motor DC dapat digunakan untuk sistem smart control pada mesin listrik [9].

Perancangan ini menggunakan desain berukuran kecil yang berfungsi sebagai prototipe untuk penempatan sensor dan alat yang digunakan. Untuk pemrosesan suara menggunakan modul voice recognition V3, kemudian mikrokontroler arduino UNO sebagai pengolah data suara dari database sensor sekaligus pengatur kecepatan motor DC. Driver motor H-bridge digunakan untuk mengubah arah putaran motor dari pembangkit PWM arduino UNO . Perhitungan kecepatan pengendalian membandingkan dengan pengukuran secara alat keseluruhan dan pengukuran secara manual dengan memasukkan tegangan secara bertahap [10].

\section{METODE PENELITIAN}

Metode perancangan yang digunakan dalam pembuatan alat, metode berupa perancangan hardware dengan menggunakan modul voice recognition V3 untuk pemrosesan suara. Mikrokontroler untuk mengolah data dan sekaligus sebagai pengatur kecepatan motor DC. Software yang dibuat menggunakan MATLAB dan Arduino IDE. Proses pertama dengan melakukan pelatihan (training) sebagai ucapan dari perintah. Tujuan dari training ini adalah untuk perintah suara yang diinginkan dapat disimpan. Diharapkan dari proses training ini user dapat mengakses sistem yang telah dibuat.

Untuk pengujian sistem dilakukan dalam lingkungan yang berbeda. Tujuan dari pengujian ini melihat dari segi sensitivitas alat yang dipakai. Untuk pengoperasian alat, pengguna akan mengucapkan perintah melalui mikrofon. Kemudian akan melakukan verifikasi perintah suara yang sudah diucapkan. Jika sesuai dengan data di database saat training, maka sistem akan membaca data itu valid atau tidak.

\subsection{Bahan dan Alat Penelitian}

Pengaturan Kecepatan motor DC dilakukan dalam 2 tahapan pengambilan data, yaitu proses pelatihan data suara perintah dan pengambilan data secara keseluruhan alat. Pada sensor voice recognition V3 memang saling dirancang terhubung oleh Arduino Uno. Sehingga pada proses train/pelatihan suara dilakukan melalui software Arduino IDE selaku pengembangan dari mikrokontroler.

Alat penelitian yang digunakan terdiri dari hadware dan software. Hadware yang digunakan untuk pengambilan data, sensor voice recognition V3, LED (Light Emiting Diode), I2C (Inter Intregated Circuit), LCD, Driver L298N, Motor DC 12V, Tachometer dan akrilik laptop yang digunakan dalam penelitian ini memiliki spesifikasi windows 10 pro, Intel® Celeron (R) CPU N2840 @ 2.16 GHz, Installed Memory (RAM) 
2,00 GB, media penyimpanan $500 \mathrm{~GB}$. Perangkat lunak digunakan untuk membantu dalam pengambilan data suara software, Arduino IDE dan MATLAB R2019b.

Arduino IDE merupakan kependekan dari Intregated Development Environment, atau secara bahasa mudahnya merupakan lingkungan terintegrasi yang digunakan untuk melakukan pengembangan. Disebut sebagai lingkungan karena melalui software inilah Arduino dilakukan pemrograman untuk melakukan fungsifungsi yang dibenamkan melalui sintaks pemrograman. Sedangkan MATLAB (Matrix Laboratory) adalah sebuah bahasa untuk komputasi dalam bidang teknik. Matlab menggabungkan antara komputasi, visualisasi, dan pemrograman dalam satu tampilan.

\subsection{Diagram Blok perangkat}

Diagram blok terdiri dari 2 tahapan dalam perancangan sistem. Untuk yang pertama adalah diagram blok proses pelatihan dan yang kedua diagram blok sistem. Diagram blok train dilakukan untuk pemrosesan sinyal suara perintah yang akan disimpan di database sebelum proses pencocokan suara. Sedangkan blok diagram sistem menjelaskan tentang proses sistem secara keseluruhan sebagai pengaturan kecepatan motor DC menggunakan speech recognition. Perintah suara dari user yang dilakukan melalui sensor sensor voice recognition V3 module perlu dilakukan sebuah training sebelum dapat mengenali perintah suara. Training bertujuan untuk menyimpan perintah suara yang akan disimpan dalam database. Setelah proses training selesai maka proses pencocokan suara akan dilakukan oleh Arduino. Diagram blok proses training melalui voice recognition module V3 dapat dilihat pada Gambar 1.

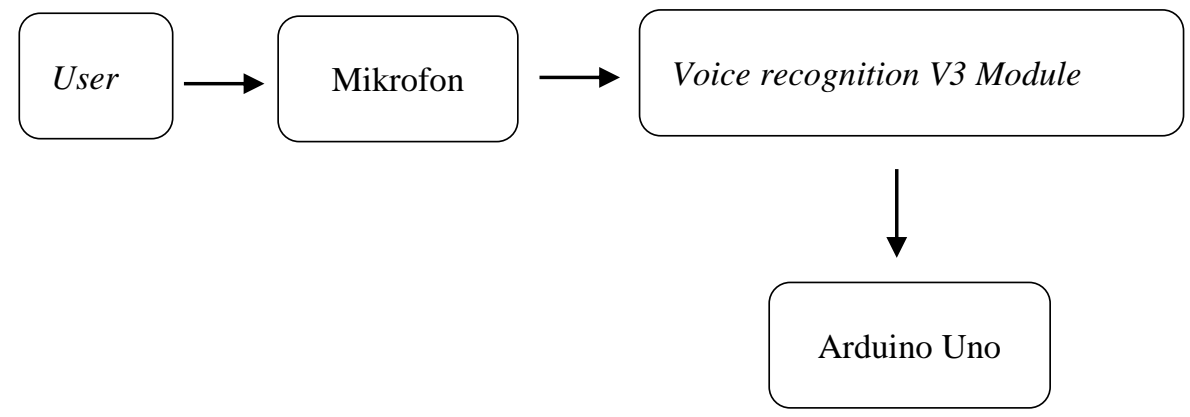

Gambar 1. Diagram blok sistem train

Pada dasarnya prinsip kerja dari alat yaitu dengan menggunakan module speech recognition V3 sebagai pemrosesan suara yang akan disimpan di database untuk pencocokan suara. Kemudian pencocokan suara akan dikirim oleh mikrokontroler Arduino sebagai pencocokan perintah suara. Sekaligus Arduino akan mengirim sinyal PWM sesuai program yang telah disematkan. Motor driver L298N dalam hal ini digunakan untuk mengatur putaran motor dengan mengubah tegangan masukan. Dapat dilihat Gambar 2. sistem dipresentasikan dalam bentuk diagram blok yang akan membantu sebagai perancangan alat pengaturan kecepatan motor DC.

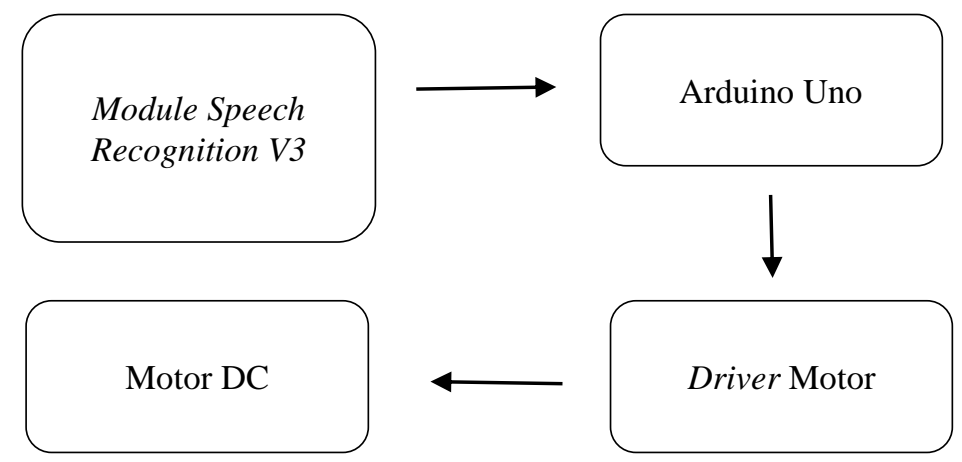

Gambar 2. Diagram blok Sistem Perangkat Keras

\subsection{Flowchart}

Perancangan flowchart pada Gambar 3 menjelaskan perintah suara yang tersimpan di database malalui proses training terlebih dahulu. Sensor yang digunakan memang dirancang terhubung dengan Arduino, sehingga pengambilan data suara/training dilakukan pada software Arduino yaitu Arduino IDE. Setelah data suara tersimpan maka proses pencocokan suara akan diproses oleh progam yang sudah disematkan pada 
mikrokontroler. Sistem dilakukan dari proses perintah suara melalui mikrofon. Kemudian dari perintah suara tersebut akan diverifikasi apakah sesuai dengan data yang sudah disimpan dari proses pelatihan. Jika ucapan atau perintah valid, maka sistem akan membaca sesuai dari perintah yang diinginkan.

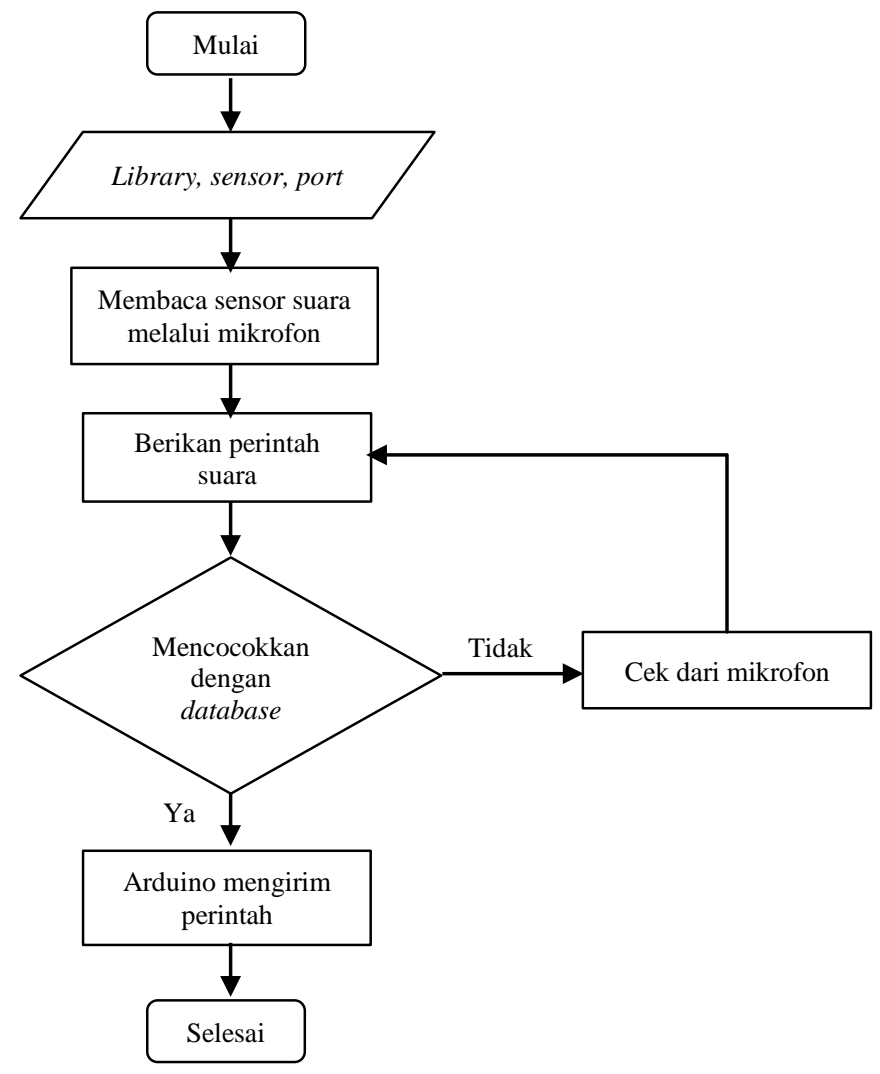

Gambar 3. Flowchat Software Tampilkan Aplikasi

Serangkaian alat yang dilakukan dari mikrokontroler menggunakan IC Atmega328 sebagai pengolah data yang memiliki (6 dari 14 pin di antaranya sebagai output PWM). Modul Voice recognition V3 yang digunakan untuk pemrosesan suara dengan pin TX dan RX sebagai pembacaan sinyal suara. Penggunaan I2C yang memiliki SCL dan SDA sebagai penghubung dari mikrokontroler ke LCD. LCD yang digunakan 16x2 memiliki 16 pin, di antaranya pin 7-14 sebagai input dan output. Driver motor DC menggunakan IC L298 tipe $\mathrm{H}$-bridge dan output 1 yang digunakan untuk mengatur motor DC. Pada rangkaian yang dibuat, selain indikator yang ada di LCD ada juga indikator LED sebagai tingkatan kecepatan atau indikator on dan off yang dimasukkan pada arduino UNO pada pin 7-13. Rangkaian alat dapat dilihat pada Gambar 4.

\section{HASIL DAN PEMBAHASAN}

Pada penelitian yang dilakukan, tujuan dari pengujian ini adalah untuk mengetahui apakah alat pengaturan kecepatan motor DC dengan menggunakan speech recognition bekerja baik dan benar. Desain yang telah dibuat berupa protipe sehingga dirancang sesederhana mungkin. Berikut alat yang sudah didesain dengan dimensi panjang $23 \mathrm{~cm}$, lebar $12 \mathrm{~cm}$, dan tinggi $8 \mathrm{~cm}$ dapat dilihat pada Gambar 5 dan Gambar 6 .

\subsection{Pengujian kecepatan motor DC berdasarkan lingkungannya}

Dari input perintah suara yang diucapkan dan kemudian ditampilkan dilayar LCD dengan berbagai mode perintah tersebut berhasil dieksekusi tanpa ada kegagalan sistem. Layar LCD dapat menampilkan informasi sesuai dengan ucapan yang diperintahkan. Pengujian pengaturan kecepatan motor DC menggunakan speech recognition dilakukan dalam kondisi lingkungan yang baik dan buruk. Pengujian sensor suara dalam keadaan lingkungan yang baik yaitu kondisi lingkungan yang tidak memilki unsur derau. Sedangkan dalam keadaan lingkungan yang buruk adalah kondisi lingkungan yang memiliki unsur derau seperti suara musik dan lingkungan publik. Dalam pengujian ini sekaligus dapat memastikan sensor suara dari segi sensitifitas, akurasi, dan ketahanannya terhadap noise. Maka didapat hasil pengujian dalam kondisi lingkungan yang baik seperti yang ditunjukkan Tabel 1 dan dalam kondisi yang kurang baik atau bisa dikatakan memiliki unsur derau yang dapat dilihat pada Tabel 2. 


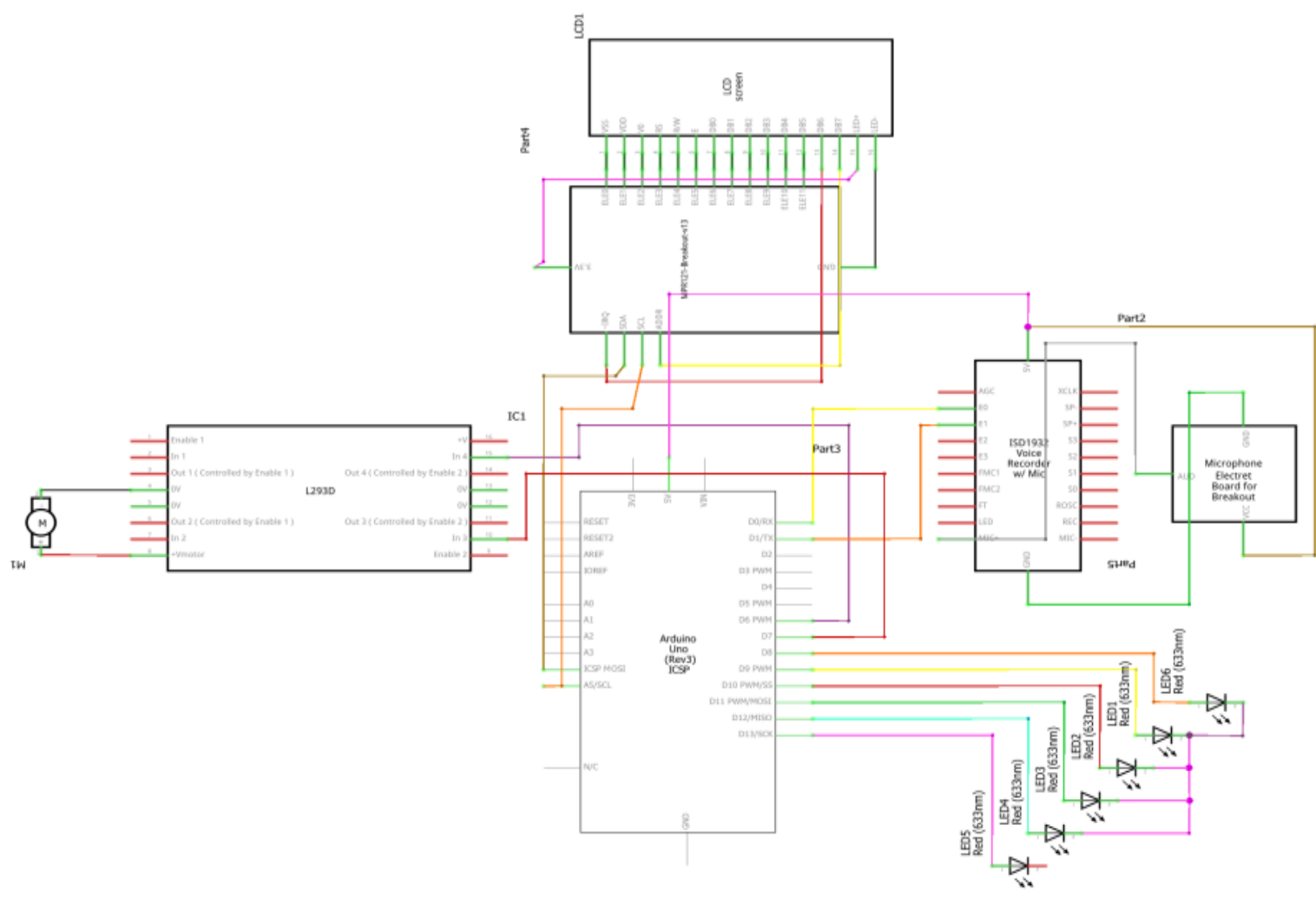

Gambar 4. Keseluruhan Rangkaian Alat

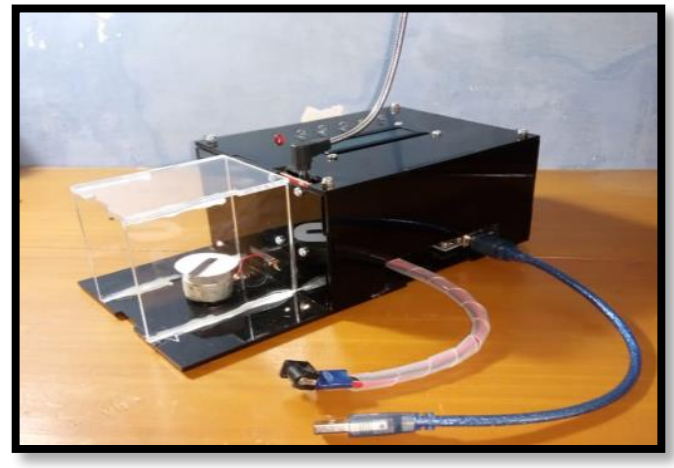

Gambar 5. Alat tampak samping

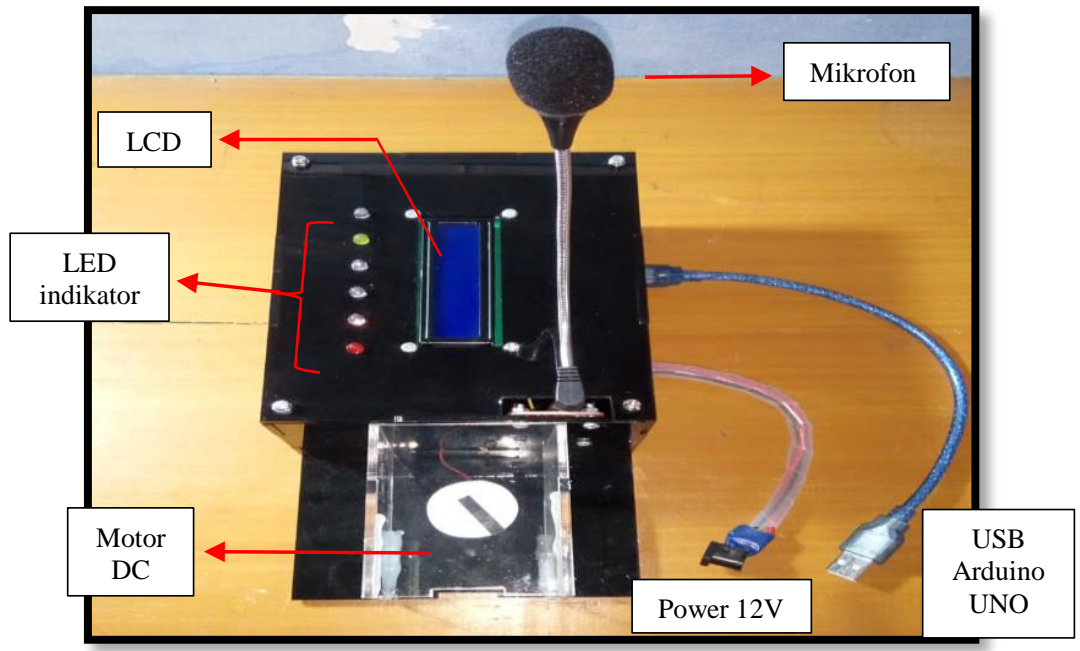

Gambar 6. Alat tampak depan 
Tabel 1. Hasil Pengujian dalam kondisi Lingkungan yang baik

\begin{tabular}{|c|c|c|}
\hline Ucapan Masukan & Jumlah Pengujian & Tingkat Keberhasilan (\%) \\
\hline Hidup & 30 & 90 \\
\hline Satu & 30 & 100 \\
\hline Dua & 30 & 100 \\
\hline Tiga & 30 & 90 \\
\hline Empat & 30 & 90 \\
\hline Mati & 30 & 80 \\
\hline
\end{tabular}

Tabel 2. Hasil Pengujian dalam kondisi Lingkungan yang buruk

\begin{tabular}{|c|c|c|}
\hline Ucapan Masukan & Jumlah Pengujian & Tingkat Keberhasilan (\%) \\
\hline Hidup & 30 & 50 \\
\hline Satu & 30 & 70 \\
\hline Dua & 30 & 60 \\
\hline Tiga & 30 & 60 \\
\hline Empat & 30 & 50 \\
\hline Mati & 30 & 50 \\
\hline
\end{tabular}

Persentase keberhasilan alat dalam mengenali ucapan perintah suara dihitung dengan rumus berikut:

$$
\% \text { Keberhasilan }=\frac{\text { jumlah keberhasilan ucapan yang dikenali }}{\text { jumlah pengujian }} \times 10
$$

Dari data hasil diatas dapat dilihat Tabel 1 dan Tabel 2 setelah melakukan 30 kali pengujian dalam lingkungan yang berbeda menunjukan pengujian sensor suara dalam kondisi lingkungan yang baik rata-rata $90 \%$ dapat dikenali sedangkan untuk pengujian dalam kondisi lingkungan yang kurang baik mengalami penurunan pengenalan ucapan yang signifikan yaitu sebesar $50 \%$.

Bila memperhatikan kondisi lingkungannya maka dalam keadaan lingkungan yang memiliki unsur derau akan jauh lebih efisien dibandingkan dengan lingkungan yang tidak memiliki unsur derau. Hal ini berkaitan dengan intonasi suara dari user sehingga sensor dapat menang sinyal suara yang diperintahkan. Pada proses pelatihan juga mempengaruhi pencocokan suara, sehingga saat proses pencocokan harus seperti saat proses pelatihan suara.

\subsection{Hasil Pengujian Kecepatan Motor DC secara Keseluruhan}

Pada pengujian ini dimaksudkan untuk melihat alat yang sudah dirancang apakah berjalan dengan baik dan benar sesuai dengan perencanaan. Dengan melihat pengujian nilai kecepatan, arus dan tegangan akan terlihat perubahan dari setiap perintah yang diberikan. Dapat dilihat pada Gambar 7 menunjukkan keseluruhan sebagai rangkaian alat pengaturan kecepatan motor DC dengan menggunakan Speech Recognition dengan melihat serial monitor pada software Arduino IDE.

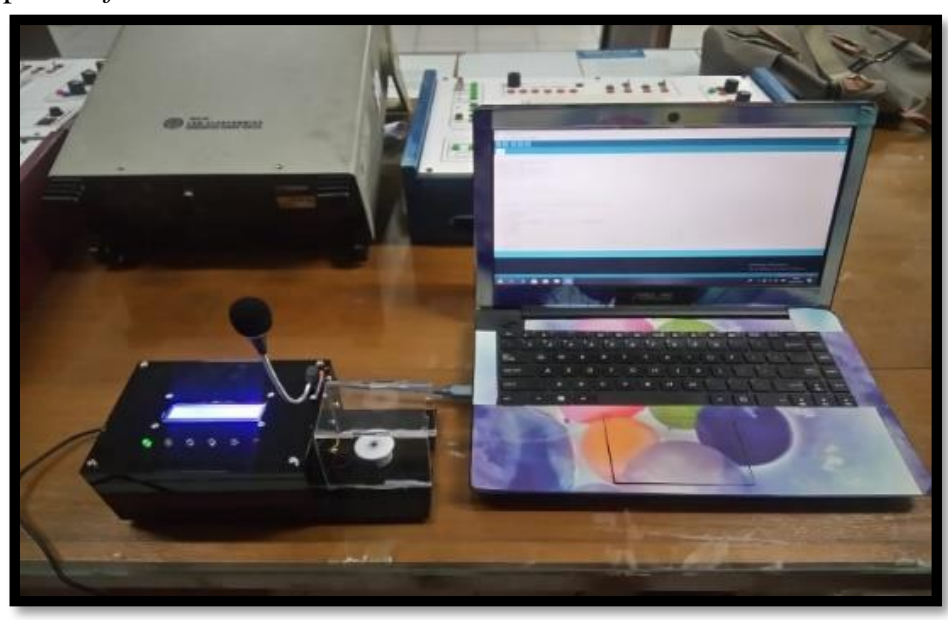

Gambar 7. Pengujian alat 
Hasil pengujian ini menghasilkan nilai kecepatan, arus dan tegangan dapat dilihat pada Tabel 3.

Tabel 3. Hasil Pengujian Hubungan Kecepatan, PWM, Tegangan, dan Arus

\begin{tabular}{|c|c|c|c|c|c|}
\hline $\begin{array}{c}\text { Ucapan } \\
\text { Masukan }\end{array}$ & $\begin{array}{c}\text { V catu daya } \\
\text { (Volt) }\end{array}$ & $\begin{array}{c}\text { Arus } \\
(\mathrm{A})\end{array}$ & $\begin{array}{c}\text { Vout } \\
(\text { Volt })\end{array}$ & PWM & $\begin{array}{c}\text { Kecepatan } \\
\text { (rpm) }\end{array}$ \\
\hline Hidup & 12 & 0,03 & 2,12 & 50 & 2915 \\
\hline Satu & 12 & 0,05 & 4,27 & 100 & 6080 \\
\hline Dua & 12 & 0,06 & 6,34 & 150 & 9100 \\
\hline Tiga & 12 & 0,07 & 8,28 & 200 & 11086 \\
\hline Empat & 12 & 0,08 & 10,48 & 255 & 13769 \\
\hline Mati & 12 & 0,02 & 0 & 0 & 0 \\
\hline
\end{tabular}

Dari data hasil pengujian pada Tabel 3 dapat dilihat ketika nilai tegangan dan arus naik maka berpengaruh terhadap peningkatan kecepatan motor DC. Proses ini menunjukkan jika nilai PWM sangat mempengaruhi perubahan kecepatan motor. Maka dapat disimpulkan mengatur PWM semakin besar maka nilai dari Vout juga akan semakin besar, dan kecepatan motor semakin bertambah. Ketika 50 PWM hasil RPM menunjukkan 2915rpm, begitu juga tegangan outputnya menjadi 2,12 volt. Seperti yang ditunjukkan pada Gambar 8 dan Gambar 9. Berikut tampilan dalam bentuk grafik dari hasil pengujian Tabel 3.
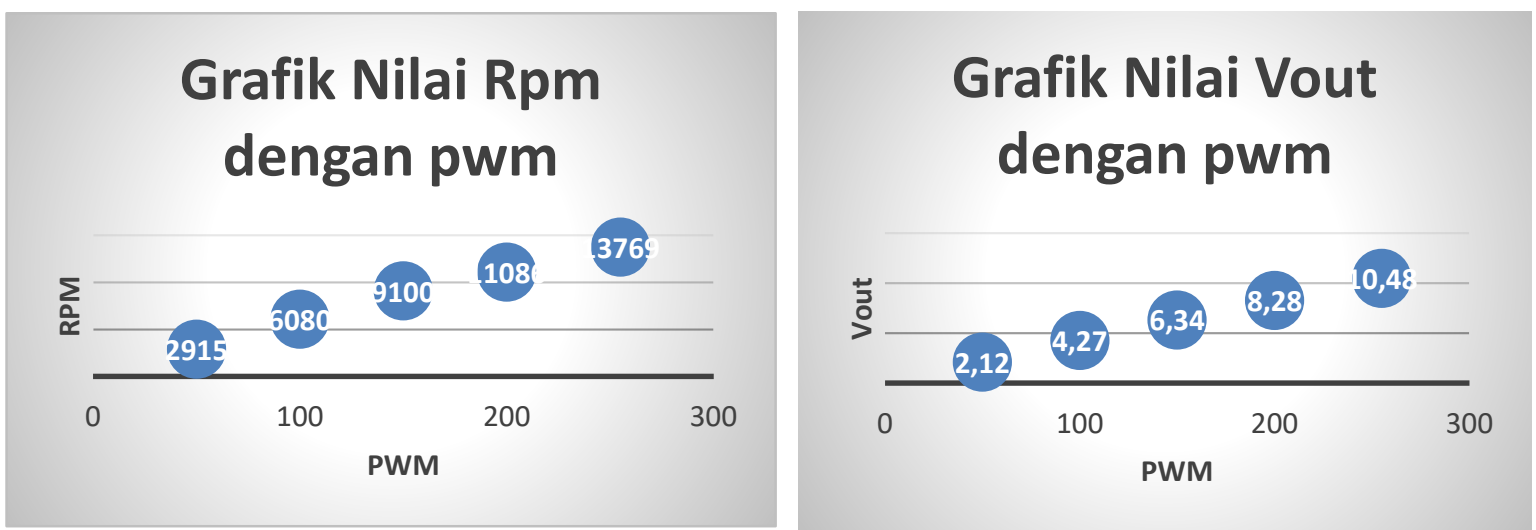

Gambar 8. Diagram grafik nilai RPM dengan PWM Gambar 9. Diagram grafik nilai Vout dengan PWM

Tetapi untuk melihat hasil pengujian ini berbanding lurus dengan kecepatan yang sebenarnya pada motor DC tersebut. Perbandingan sistem dilakukan dengan membandingkan hasil perhitungan secara keseluruhan alat dan hasil perhitungan secara manual. Maka diperlukan pengujian kecepatan motor DC secara bertahap dengan memasukkan tegangan 1-10 volt dengan tujuan memastikan alat bekerja dengan baik dan memastikan alat yang dirancang sesuai dengan pengukuran nilai kecepatan yang sebenarnya. Berikut data pengujian kecepatan motor DC secara bertahap beserta nilai hubungan kecepatan, arus dan tegangan seperti Tabel 4.

Tabel 4. Hasil pengujian masukan tegangan secara bertahap

\begin{tabular}{|c|c|c|c|}
\hline Vin (Volt) & Arus (A) & Vout (Volt) & Kecepatan (rpm) \\
\hline 1 & 0,01 & 1,05 & 1253 \\
\hline 1,5 & 0,01 & 1,54 & 1910 \\
\hline 2 & 0,02 & 2,15 & 2882 \\
\hline 2,5 & 0,02 & 2,49 & 3308 \\
\hline 3 & 0,03 & 3,00 & 4113 \\
\hline 3,5 & 0,03 & 3,48 & 4787 \\
\hline 4 & 0,03 & 4,08 & 5596 \\
\hline 4,5 & 0,03 & 4,47 & 6240 \\
\hline 5 & 0,04 & 5,07 & 7136 \\
\hline 5,5 & 0,04 & 5,46 & 7688 \\
\hline 6 & 0,04 & 6,02 & 8553 \\
\hline 6,5 & 0,04 & 6,47 & 9160 \\
\hline 7 & 0,05 & 7,03 & 9950 \\
\hline 7,5 & 0,05 & 7,40 & 10403 \\
\hline 8 & 0,05 & 8,02 & 10985 \\
\hline 8,5 & 0,05 & 8,45 & 11577 \\
\hline
\end{tabular}




\begin{tabular}{|c|c|c|c|}
\hline 9 & 0,06 & 8,80 & 11737 \\
\hline 9,5 & 0,06 & 9,40 & 12204 \\
\hline 10 & 0,06 & 9,85 & 13185 \\
\hline
\end{tabular}

Dari data Tabel 4 dapat dilihat untuk pengujian motor DC dengan memberi masukan secara bertahap dari 1-10 V jika dibandingkan dengan hasil pengujian alat secara keseluruhan hampir sama. Pengujian ini sekaligus memastikan jika hasil dari pengujian alat secara keseluruhan berbanding lurus dengan pengujian dengan memasukkan nilai tegangan secara bertahap.

Untuk memastikan kebenaran data dari pengujiannya, oleh karena itu perbandingan dengan perhitungan hasil tegangan dan kecepatan motor DC yang diukur dengan tachometer akan didapatkan konstantanya seperti berikut:

\section{Kecepatan $=$ tegangan $x$ konstanta}

Mencari konstanta tersebut didapatkan dari kecepatan motor DC dibagi dengan tegangan dari Tabel 4 akan didapat nilai konstanta yaitu $=(12864,3)$ dengan cara menjumlahkan seluruh hasil dari kecepatan dibagi dengan tegangan, kemudian dibagi dengan jumlah data. Data yang digunakan berjumlah 10, jika lebih banyak akan semakin bagus karena akan mendekati nilai sebenarnya. Perhitungan dapat dilihat seperti berikut:

Diambil dari perintah "hidup" yang memiliki tegangan Vout sebesar 2,12 Volt sehingga dihasilkan:

$$
\text { Kecepatan }=2,12 \times 12864,3=2727 \mathrm{rpm}
$$

Jika dilihat dari pengukuran melalui tachometer sebesar $2915 \mathrm{rpm}$, dan melalui perhitungan manual sebesar 2727. Perbedaan dari kecepatan tersebut dapat dipengaruhi karena faktor pengukuran saat pengujian. Disebabkan pada inputan catu daya pengujian masukan dari 1-10 Volt tidaklah begitu akurat.

\section{KESIMPULAN}

Berdasarkan hasil penelitian yang telah dilakukan mulai dari tahap pembuatan aplikasi, perancangan sistem, pengambilan data, pengujian sistem, kemudian analisa hasil pengujian dan pembahasan maka dapat disimpulkan sebagai berikut. Pembuatan aplikasi dan pengambilan data telah berhasil melakukan pembacaan dan menampilkan perubahan kecepatan. Aplikasi yang dibuat dapat berjalan dengan baik. Perancangan sistem yang dibuat telah menghasilkan Pengaturan Kecepatan Motor DC Menggunakan Speech Recognition. Berdasarkan perintah suara yang diucapkan. Pengujian yang dilakukan dalam lingkungan yang berbeda memiliki perbedaan hasil yang cukup signifikan. Ketika pengujian dalam lingkungan yang baik menghasilkan tingkat keberhasilan $90 \%$, sedangkan dalam lingkungan yang buruk sebesar 50\%. Perbedaan ini disebabkan dari sensitivitas sensor yang digunakan. Kesalahan pada proses pengucapan dapat terjadi karena perbedaan intonasi ketika proses pelatihan perintah suara.

\section{REFERENSI}

[1] R. Birdanyansyah, N. Sudjarwanto, O Zebua, "Pengendalian Kecepatan Motor DC Menggunakan Suara Berbasis Mikrokontroler Arduino," ELECTRICIAN, Vol 9, no 2, pp 1-12, 2015. DOI: https://doi.org/10.23960/elc.v9n2.168

[2] M. Rusdi, A. Yani, "Sistem Kendali Peralatan Electronik Melalui Media Bluetooth Menggunakan Voice Recognition," $J$ of Electrical Technology, Vol 3, no 1, pp 1-7, $2018 . \quad$ DOI: https://doi.org/10.30743/infotekjar.v3i2.905

[3] A. Imario, D. Sudiharto, E. Apriyanto, "Uji Validasi Suara Berbasis Pengenalan Suara (Voice Recognition) Menggunakan Easy VR 3.0," Prosiding SNATIF, 2017. Online

[4] A. Dani, A.Andriyansyah, D. Hermawan, "Perancangan Aplikasi Voice Command Recognition Berbasis android dan arduino Uno," J. Tek. Elektro, Vol 7, no. 1, pp 1-9, 2016. DOI: https://doi.org/10.22441/jte.v7i1.811

[5] Baharuddin, R. Sajdad, M. Tola, "Sistem Kendali Kecepatan Motor DC berbasis PWM (Pulse width Modulation)," Jurnal Teknologi Terpadu, Vol 4, no 1, pp 1-12, 2012. Online

[6] Royan, A Luqman, " Aplikasi motor DC-Shunt Untuk Laboratory Shaker Menggunakan Metode PWM (Pulse Width Modulation ) Berbasis Mikrokontroler Atmega 32," Media Elektrika, Vol 8, no 1, pp 1-19, 2015. DOI: https://doi.org/10.26714/me.8.1.2015.\%25p

[7] Muchlas, Sunardi, T Antoro, " Pengendalian Kecepatan Motor DC Dengan Metode Look Up Table Berbasis Mikrokontroler AT89C51," TELKOMNIKA, Vol 4, no. 1, pp 1-10, 2006. DOI: https://doi.org/10.12928/telkomnika.v4i1.1238

[8] D. Setiawan, "Sistem Kontrol Motor DC Menggunakan PWM Arduino Berbasis Arduino Sistem," Jurnal Sains, teknologi dan industri, Vol 15, no 1, pp 33-34, 2017. DOI: http://dx.doi.org/10.24014/sitekin.v15i1.4131

[9] D. Handoko, P. Kasih, "Voice Recognition untuk Sistem Keamanan PC Menggunakan Metode MFCC dan DTW," Generation Journal, Vol 2, no. 1, pp1-12, 2018. DOI: https://doi.org/10.29407/gj.v2i1.12058

[10] J.Ardi, Nurussa'adah, M. Rif'ain, "Implementasi Sistem Voice Recognition Pada Robot Pemindah Object sebagai Sistem Navigasi," Jurnal Mahasiswa TEUB, Vol 2, no. 1pp 1-6, 2014. 
http://elektro.studentjournal.ub.ac.id/index.php/teub/article/view/192

\section{BIOGRAFI PENULIS}

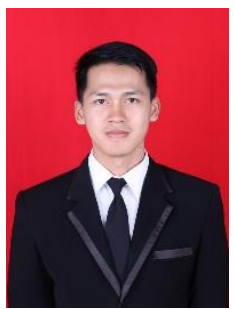

Firda Andriyan adalah mahasiswa program studi S1 Teknik Elektro di Universitas Ahmad Dahlan angkatan tahun 2015 dan telah menyelesaikan pendidikan tersebut pada tahun 2019. Bidang peminatannya adalah otomasi industri

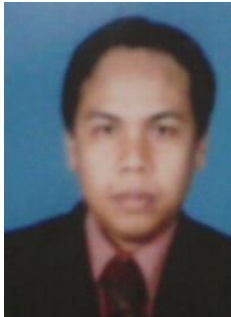

Wahyu Sapto Aji adalah Dosen di Program Studi Teknik Elektro, Fakultas Teknologi Industri, Universitas Ahmad Dahlan, Yogyakarta 